\title{
Network Composition, Individual Social Capital and Culture: Comparing Traditional and Post- Modernized Cultures
}

\author{
by Julia Häuberer and Alexander Tatarko \\ Universität Hamburg; National Research University - Higher School of Economics
}

Sociological Research Online, 22 (2), 10

$<\mathrm{http} / / /$ www.socresonline.org.uk/22/2/10.html>

DOI: $10.5153 /$ sro.4239

Received: 25 May 2016 | Accepted: 1 Feb 2017 | Published: 31 May 2017

\begin{abstract}
This article addresses the influence of cultural background on the access to social capital in family and friendship networks. We will analyze four different culture groups: Czechs and Russians (Muscovites) both representing post-modernized cultures and Dagestans and Chechens both representing traditional cultures. The data will be analyzed using univariate comparisons and fixed effects regressions. Our results indicate that cultural background does not play such a crucial role for social network composition and social capital access through the family or friends. In both cases, Dagestans, Chechens and Czechs access significantly less social capital than do the Russians (Muscovites), however only if Russians (Muscovites) are in frequent contact with their families or have large friendship networks. In other words, network embeddedness seems to play a more important role than cultural background for social capital access.
\end{abstract}

Keywords: Individual Social Capital, Social Networks, Culture, Modernization, Tradition, Resource Generator

\section{Introduction}

1.1 Every day, thousands of people begin to migrate into a new life. Reasons for migration are manifold. Economic security as well as the escape from war scenarios are motives for migration. In the country of destination, the migrants are often faced with different values than those that are common in their country of origin. Frequently individuals migrate from less developed economies to industrialized countries, so that individuals migrate from traditional to modernized cultures. In traditional societies, individuals hold traditional and survival values. Modernized cultures are characterized by secular-rational and self-expression values (Inglehart 1997; Inglehart \& Baker 2000). Traditional values in contrast to secular-rational values indicate that religion is very important. Respect for authority, God, country and family are closely interrelated in traditional societies. In traditional societies the main goal in life is to make parents proud. Societies in which secular-rational values prevail, contacts outside of the family are more important than family contacts. The key component of survival in contrast to self-expression values is the opposition of materialistic and post-materialistic values. Many studies show that these values reflect an inter-generational shift from emphasis on economic and physical security to emphasis on self-expression, subjective well-being and life quality (Inglehart 1997). Accordingly, migrants sometimes have to adapt to a completely different value system in their country of destination. Otherwise integration into the destination society is difficult. individuals coming from traditional societies will be different than family networks of individuals who come from modernized societies. The same can be said for friendship networks as they are more important in modernized societies than in traditional societies. Furthermore, social networks are a precondition for individual social capital 
access i.e. social resources. According to Bourdieu (1986), social capital, in addition to economic and cultural capital, is a crucial tool that distinguishes individuals from upper classes to those from lower classes. Accessing social capital thus means having the potential to reach and maintain a higher status in a society (Bourdieu 1986; Lin 2001). Therefore, if migrants have social capital in their country of destination, their chance for social integration is good.

1.3 Until now, social capital access was primarily analyzed. Recently studies (cf. Finsveen \& van Oorshot 2008; Häuberer 2014; Mollenhorst et al. 2014) have analyzed the role that network embeddedness plays for social capital access. To broaden their knowledge regarding the impact of cultural background, this paper addresses the following questions: how do the networks of representatives of traditional cultures differ from the networks of members of modern cultures? What does this mean for social capital access? We have based our research on the cultural map of Inglehart \& Welzel (2010) and have analyzed two unique empirical studies that include respondents from traditional and modernized societies. These studies were conducted separately, but gave answers to similar questions: They asked where individuals access social resources and social capital; which network parts are crucial for social capital access and how individuals profit from the access to specific social resources. For this paper, we have focused on the connection between an individuals' social network embeddedness; meaning the size and quality of networks an individual is part of and social capital access, i.e. access to social resources in order to analyze the differences between two sets of respondents: those from societies holding predominantly secular-rational and self-expression values (later post-modern cultures) and those from societies holding predominantly traditional and survival values (later traditional cultures). Chechens and Dagestans represent cultures from the North Caucasus of the Russian Federation with predominantly traditional/survival values, while Czechs and Russians from Moscow represent cultures with rational-secular and self-expression values. We compare contact within the family, the size of the friendship network and participation in voluntary associations of the respective groups and assess how these factors influence the social resource access that is valuable for instrumental action.

\section{Social Capital}

2.1 Social capital has evolved into a key concept in the social sciences because it helps to explain the success of individuals in their professional life (Behtoui 2007; Burt 2000; Granovetter 1973; Lin 1999, 2001) and the functioning of a society (Engström et al. 2008; Kawachi et al. 1997, 1999; Paxton 2002; Putnam 2000). Having social capital means to have better chances for social integration. Although conceptualizations of social capital are manifold (cf. Coleman 1988, 1990; Putnam 2000; Lin 2001; for an overview seeHäuberer 2011), most concepts share Bourdieu's (1986: 248) idea that social capital consists of "actual or potential resources linked to a membership in a group". We share this view and refer to social resources as social capital because social resources initially represent what is meant by capital. Resources can be used to attain goals, and individuals can easily invest in their volume by creating networks. Individuals access concrete social resources, such as help with the annual tax declaration or help with shopping when they are sick. This resource access depends on their prior investment in the network. Spending time with network members and assisting them when they need help forms a basis for exchanging social resources. Help represents a donation of resources and thus the beginning or maintenance of resource transfer. This action builds social capital (Plickert et al. 2007: 406).

2.2 Concrete access to social capital depends on the number of social contacts an individual has, the strength of the ties an individual has to these persons and the amounts of social resources these individuals possess (Lin 2001). Thus, strong ties or cohesive networks (Coleman 1988) are expected to promote mutual trust and the willingness to cooperate (Flap \& Völker 2001), whereas weak ties are useful for accessing information (Granovetter 1973).

2.3 Empirical results demonstrate these connections. Analyzing Eurobarometer data, Häuberer (2014) indicated that social resource access with regard to resources that are useful for expressive action strongly depends on embeddedness in friendship networks and participation in voluntary associations. The same relation was revealed by Finsveen and van Oorshot (2008) in an analysis of ISSP data. Individuals who live in large households, who have regular contact with friends, colleagues and neighbors and who participate in associations (with the exception of associations pursuing political goals) have better access to social resources (Häuberer 2014). Recently, Mollenhorst et al. (2014) showed that social resource access depends on the opportunity to maintain or create relationships. The persons with whom an individual is in regular contact are those perceived as sources of social resources. 
access (see also Häuberer 2011: 150). Individuals are embedded in informal networks composed of family members or friends and formal networks created by participation in voluntary associations (Putnam 2000). We expect the composition of the networks to mediate social capital access, and we formulate hypothesis $\mathrm{H} 1$ : Embeddedness in networks positively influences the amount of social capital accessed.

2.5 Further important preconditions for social capital access are an individuals' cultural background and values.

\section{Cultural Background and Social Capital Access}

2.6 Social network formation and social capital access are determined by historical, economic, institutional and cultural factors.

2.7 Culture forms the characteristics of the social environment in which an individual lives and influences the way people behave (Berry et al.1997: 66). Berry et al. (1997: 66) suggest that the behavior of an individual is a combination of personal traits such as attitudes, personal characteristics and the social environment to which the culture relates. Therefore, we expect culture to affect how individuals create their own social networks and how they invest in networks which in turn influences individual social capital access. Ideas about the cultural causation of social capital have been expressed repeatedly (cf. Allik \& Realo 2004; Fukuyama 1995; Putnam 1994).

2.8 We expect miscellaneous effects due to different cultural values on social capital access. According to Inglehart (1997) we distinguish a) traditional values and secular-rational values and b) self-expression values in contrast to survival values. Different studies (cf. Fischer 1982; Granovetter 1973; Höllinger \& Haller 1990; Litwak \& Szelenyi 1969) show the effects of values on network composition in Figure1. The combination of traditional and survival values is common in traditional societies, whereas the combination of secular-rational and selfexpression values is common in post-modernized societies (Inglehart \& Welzel 2005, 2010). A society that has a low level of sociocultural modernization and dominance of traditional values is called a "traditional society". Traditional values are accompanied by the importance of multigenerational family structures. Survival values include collectivism and strong family orientation, whereas post-modernized values highlight the importance of extra-family networks. Nevertheless, studies by Litwak \& Szelenyi (1969), Fischer (1982) and Hofferth \& Iceland (1998) indicate that family relations remain important in post-modernized societies if the structure of family relations changes. Accordingly, we assume that social capital access of representatives of traditional and modern societies differs with regard to friends, but not with regard to family. Thus, we formulate Hypothesis H2a:

Individuals of traditional and post-modernized cultures receive individual social capital from their family ties equally. Because post-modern societies are likely to combine secular-rational values and self-expression values, we find pluralized life forms and individualism in these societies. Relationships are also formed outside the family (see Höllinger \& Haller 1990). Accordingly, we formulate Hypothesis H2b:Individuals in post-modernized cultures receive more individual social capital from their friendship relations than they do in traditional cultures. 


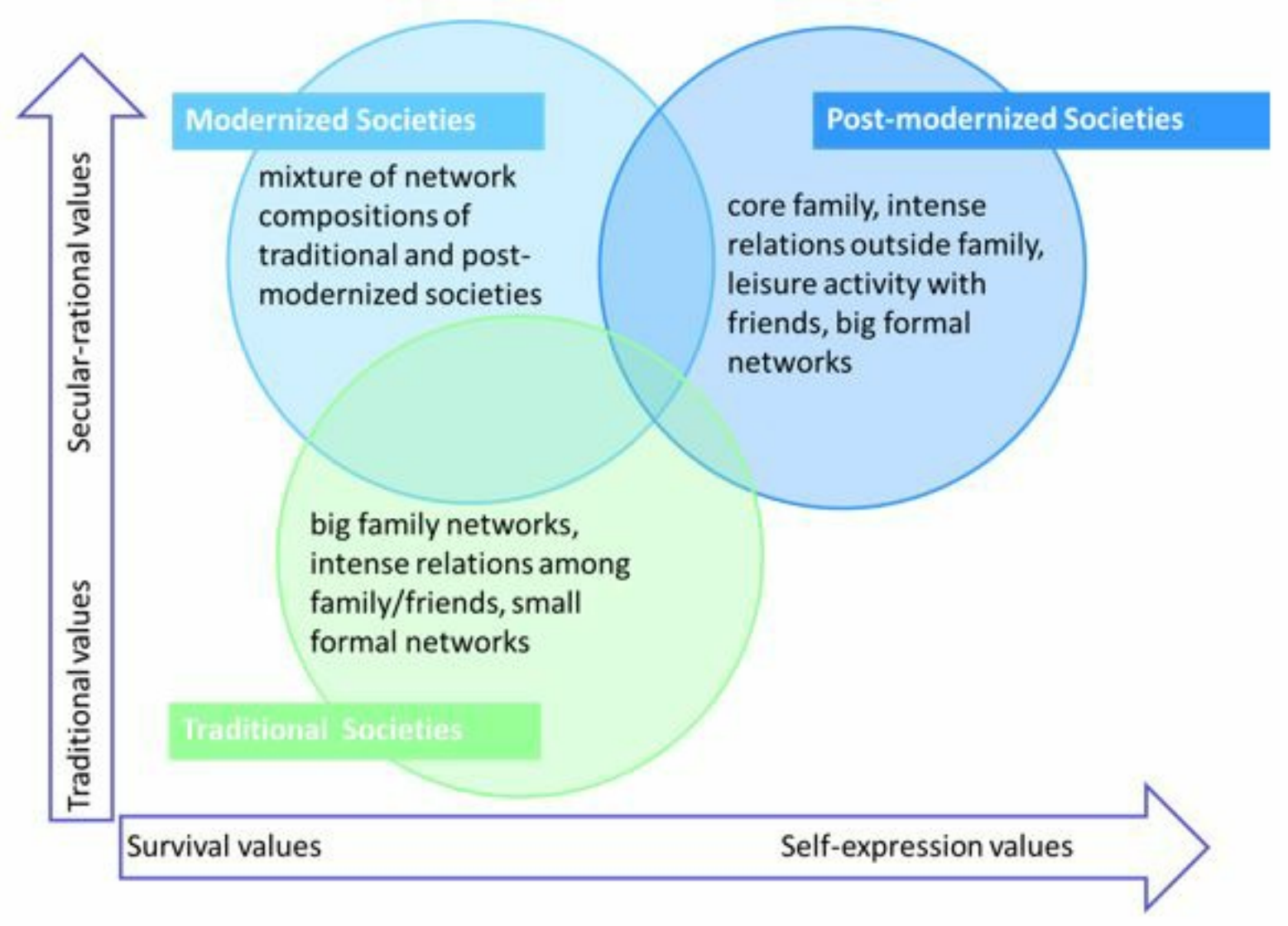

Figure 1. Cultural Values and Social Network Composition

Notes: Figure based on cultural map of Inglehart, Welzel (2010)

\section{Studied Groups: Cultural Differences of Czechs, Russians (Muscovites), Chechens, and Dagestans}

3.1 To analyze the relations among social network embeddedness, social capital access and cultural background, we have compared four cultural groups - Czechs, Russians (Muscovites), Chechens, and Dagestans - whose representatives have both similar and different features. Russians are represented by individuals living in Moscow[2].

3.2 First, all four countries are post-communist countries (cf. Inglehart \& Baker 2000). The Russians (Muscovites), Chechens and Dagestans live in the Russian Federation and the Czechs live in the Czech Republic - once part of the former socialist Czechoslovakia. Accordingly, the ideology and social system are similar for the members of these cultures. We know that under communism, informal networks were formed as an alternative to the state and forced participation in formal networks (Raiser et al. 2001). In this sense, the researched cultural groups have a similar historical past. They all transitioned from a socialist system, where informal networks prevailed and provided social capital, to a democratic system in which formal networks have grown in addition to informal networks. It is plausible that in all of the researched groups, family and friends still play a major role in comparison to civic networks. Regarding the institutional framework, Russians (Muscovites), Chechens, and Dagestans live in the same social welfare system because they are all part of the Russian Federation. Only the Czech system differs. Historically, the welfare systems transitioned from a universal socialist welfare system to a hybrid welfare system. Kollmorgen (2009) classifies the Russian system as a rudimentary state paternalist system in which family, market and the state play central roles in providing welfare. The Czech system is a state-managed conservative welfare system in which the family and the state play central roles. Both systems realize only marginal redistribution among different strata. Because both welfare systems are based on family and state, they have similar effects on social capital access. The cultural differences between Dagestans and Chechens, on the one hand, and Russians (Muscovites) and Czechs, on the other hand, are more important in determining social capital access.

3.3 In order to classify the researched cultural groups as traditional and post-modernized, we first used different criteria derived from relevant literature on the subject (cf. de Vries 1961; Chance 1965; Dressler 1982, 1994; Inkeles \& Smith 1974). Second, we underlined our conclusions with data from a Russian study and the 
Religion. Most Russians and Czechs are Christians (in particular Russian Orthodox and Catholic). In contrast, Dagestan and Chechnya are predominantly Islamic cultures. In Chechnya and Dagestan, approximately $43 \%$ of the population regularly attend a mosque (Caucasus online 2012), whereas in Moscow, only approximately $14 \%$ of the population goes to church on a regular basis (at least once per month) (Izvestiya 2014). Furthermore, the Czech Republic is the most secular country in Europe: in $2011,79 \%$ of the population admitted being atheists (Czech Statistical Office 2013b). Religious involvement based on the cultural map of Inglehart and Welzel (2010) suggests that Czechs hold the most secular-rational and self-expression values, followed by Russia. Chechens and Dagestans hold more traditional and survival values.

\section{Place of residence (community urbanization level). Urban residents can be considered representatives} of a more modernized group than rural residents (Inkeles \& Smith 1974: 292), usually associated with secularrational values (cf. Inglehart \& Welzel 2010). The peoples of the North Caucasus (in our case, Chechens and Dagestans) live in less urbanized environments than Russians (Muscovites) and Czechs. In 2012, 73\% of Czechs lived in urbanized areas (cf. World Bank 2013a). Russian respondents in our sample come from the Moscow region and also live in an urbanized area. Only 35\% of Chechens and $45 \%$ of Dagestans live in urbanized areas (Russian Federal State Statistics Service 2010) which indicates their traditional character. This finding reiterates the traditional values of Chechens and Dagestans and the secular-rational values of Russians (Muscovites) and Czechs.

The level of well-being. In General, post-modernization is characterized by increased economic wellbeing, resulting in higher levels of individual well-being (Inglehart \& Welzel 2010). Such cultures are likely to hold self-expression values. In our sample, the Russians (Muscovites) living in the European part of Russia and the Czechs have a higher standard of living than most of the residents of the North Caucasus Republics of Russia. For instance, in 2012, Dagestan revealed a Gross Domestic Product per capita (GDP) of \$7,509 USD. Chechnya's GDP was lower than that of Dagestan at \$4,495 USD. In Moscow, the GDP reached \$58,085 USD (Russian Federal State Statistics Service 2013), and the Czech Republic had a GDP of \$18,608 USD (World Bank 2013b). Accordingly, Dagestans and Chechens are likely to hold survival values, whereas Czechs and Russians hold self-expression values.

3.7 Education level. With the (post)modernization of culture, the level of education of a culture's representatives also increases (Inkeles \& Smith 1974: 297). In the European part of Russia and the Czech Republic, the education level is higher than that of the residents of the North Caucasus. In 2012, the share of the population with a higher education in Moscow was $41 \%$, but it was only $18 \%$ in the Republic of Dagestan and in the Chechen Republic this index was less than 15\% (RIA-News 2012). In the Czech Republic, 37\% of individuals held at least a qualification equivalent to A-level in 2011 (Czech Statistical Office 2013a).

3.8 Relational orientation. Representatives of traditional cultures are oriented mainly toward intra-family relations, whereas the representatives of post-modernized cultures are focused on extra-family social contacts (Inglehart \& Welzel 2010: 563), which is true for Czechs and Russians (Muscovites). Furthermore, representatives of the peoples of the Russian North Caucasus place greater importance on the values in Schwartz's methodology (Schwartz 2006; 2012) that describe other people's orientation (e.g. universalism, benevolence). The Muslim peoples of the North Caucasus especially favor values such as conformity, tradition, and universalism (Lebedeva \& Grigoryan 2013).

3.9 These indicators allow us to classify Russians (Muscovites) and Czechs as post-modernized and Chechens and Dagestans as traditional groups. However, is this in line with empirical results regarding the value orientation of these individuals? Because Dagestan and Chechnya did not participate in the World Values Survey, we cannot simply classify them according to the cultural map of Inglehart \& Welzel (2010). However, we can assess the level of modernization of the four groups based on the values of "tradition" using the theory of basic human values of Schwartz (Piurko et al. 2012). His questionnaire of values is used in the well-known "European Social Survey" (ESS). According to Schwartz's theory, the value of "tradition" is one of the 10 basic values of people in different cultures (Schwartz 2012; Schwartz \& Fischer 2012). The defining goals of tradition are respect, commitment, and acceptance of the customs and ideas that one's culture or religion provides. "Tradition entails subordination to more abstract objects - religious and cultural customs and ideas. As a consequence, conformity values exhort responsiveness to current, possibly changing expectations. Tradition values demand responsiveness to immutable expectations from the past" (Schwartz 2012: 6-7). 
3.10 Measures of tradition and religiosity can be found in the Russian study "Values and Economical Behaviour: Testing explanatory models in experiments and field studies" which included Russians from Moscow, Chechens and Dagestans as well as the European Social Survey (ESS 2012), including the Czech Republic. Comparing the data supports our previous classification (see Table 1).

Table 1. Mean Values of Tradition and Religiosity of Russians, Czechs, Dagestans and Chechens

\begin{tabular}{lllll}
\hline & $\begin{array}{l}\text { Russians* } \\
\mu(\sigma)\end{array}$ & $\begin{array}{l}\text { Czechs } \\
\mu(\sigma)\end{array}$ & $\begin{array}{l}\text { Dagestans* } \\
\mu(\sigma)\end{array}$ & $\begin{array}{l}\text { Chechens* } \\
\mu(\sigma)\end{array}$ \\
\hline Tradition & $3.9(0.75)$ & $3.9(1.1)$ & $4.3(0.72)$ & $4.5(0.48)$ \\
Religiosity & $4.9(2.6)$ & $2.4(2.8)$ & $6.1(2.7)$ & $9.3(1.3)$ \\
\hline
\end{tabular}

Notes: standard deviations in parentheses; * data of Values and Economical Behaviour 2012, + data of European Social Survey 2012, Item wordings: Tradition: "Please tell me how much each person is or is not like you: Tradition is important to him. He tries to follow the customs handed down by his religion or his family." (1 not like me at all, 6 - very much like me), Religion: "How religious are you?" (0 - not religious at all, 10 - very religious).

3.11 As shown in Table 1, the average values of "tradition" among Russians and Czechs are the same, but the averages are higher for Dagestans, especially for Chechens. These differences are statistically significant. The level of religiosity is also statistically significantly higher among Dagestans and Chechens in comparison to Russians and Czechs. This finding supports our prior classification and allows us to conclude that Dagestans' and Chechens' cultures are more traditional than are the cultures of the Russians and the Czechs.

3.12 Therefore, we divide the four researched groups into two cultures: a traditional culture from North Caucasus with predominantly traditional and survival values and a post-modernized Slavic culture with predominantly secular-rational and self-expression values. Regarding our classification of values and social network composition in Figure 1, we find Chechens and Dagestans in the lower left and Czechs and Russians in the upper right.

\section{Data and Measures}

\section{Data}

4.1 To test our hypotheses, we analyzed data from two surveys administered in the Czech Republic and in the Russian Federation. In 2008, the Czech survey, "[...]", was conducted as second part of a test-retest study. The study was a telephone survey and included 129 respondents ${ }^{[3]}$ over 18 . Possible respondents were randomly chosen from the telephone register. At the beginning of the interview, they were asked if they fit a quota regarding gender, age and education to represent the Czech society. If they fit the quota, they were included in the sample, if not, they were not interviewed. The quota itself was constructed in accordance to official Czech statistics. The Russian survey, "[...]", was administered between June 2012 and August 2012. A representative sample of Russian adults from two large districts was drawn, and people aged 18 to 60 years of age (inclusive) residing in private households were selected. We employed a multistage (3-stage) area sample. The effective total sample size was 2,058 interviews: 1,024 personal interviews in the Central Federal district including the city of Moscow and 1,034 personal interviews in North-Caucasus Federal district. The survey was conducted in these regions because there is a considerable difference in their levels of socio-cultural modernization.

For the analyses presented here, we selected a subsample of ethnic Russians (from Moscow),

Dagestans and Chechens ( $\mathrm{N}=718$, see Table 2). We used empirical data from three regions of Russia: in the Moscow City (Central Federal district), Republic of Chechnya (North-Caucasus Federal district), and Republic of Dagestan (North-Caucasus Federal district). Ethnic Russians were included in the sample selected in Moscow City. Ethnic Chechens were interviewed in the Republic of Chechnya. Dagestan is the most multi-ethnic republic of Russia, where 33 ethnic groups live. As most of the ethnic groups in Dagestan are very homogenous regarding their cultural characteristics, we identified them as "Dagestans" in our sample. Finally, we merged the data with the Czech sample.

\section{Dependent variables}


Social capital. We measured social capital by an individual's social resources received from informal networks of family and friends. Such resources range from receiving help with house repair to legal and financial assistance (Häuberer 2011; van der Gaag \& Snijders 2005; Verhaeghe \& Tampubolon 2012). We modified the wording where necessary to fit the contexts. This method asks how many family members and how many friends/acquaintances the respondent has who "can advise them on legal or bureaucratic issues" and "are able to help the respondent to find a job" etc. (see Figure 5 and 6). Using factor analysis, we constructed two factors measuring social capital: "Social Capital among Family" and "Social Capital among Friends" (for factor construction and correlation matrices see Appendices A.2.1. and A.2.2.).

\section{Independent variables}

4.4 Family contact. We assessed embeddedness in the family network by asking respondents about their contact frequency with relatives, like parents, brothers and sisters etc. (see Figure 2; Häuberer 2011; van der Gaag \& Snijders 2005; Verhaeghe \& Tampubolon 2012). We chose this measure because it indicates the network size and the intensity of relations within the family. The contact frequency with family members was measured on a four-point scale where 3 indicates contact three or more times a month and 0 indicates the absence of a living relative of this kind. We used value 1 when no contact prevailed but the relative was alive because we expect that such a contact can be activated if needed. Furthermore, we constructed a factor for "contact family" on the basis of a polychoric correlation matrix to account for the categorical variables (see also A.2.3.).

Friendship network. We measured the network of friends by asking for the respondents' number of friends in the workplace, in the neighborhood and elsewhere (cf. Häuberer 2011). From these items, we also constructed a factor for "friends network" (see A.2.4.).

Participation in voluntary associations. We measured embeddedness in a formal network with organizational involvement by asking the respondents about their participation frequency in four different types of associations (see Figure 4; cf. Häuberer 2011; Yang 2007; Beilmann \& Realo, 2012). We dichotomized the variables for two reasons: first, the participation frequency was measured in the Czech survey on a three-point scale, but the Russian survey used a five-point scale. Second, the participation rates were extremely low in both countries. Differentiating contact frequencies does not add any explanatory value. All items were used to construct the factor "participation in voluntary associations" on the basis of a polychoric correlation matrix to account for the categorical variables (see A.2.5.).

Cultural background. Cultural background was measured by the origin of the respondent, indicated by dummy variables (Czech, Russian, Dagestan and Chechen origin).

\section{Control variables}

4.8 To control for the respondents' background, we included sex, age and education, EGP classes, employment status and size of place of residence. Education was measured on a four-point scale indicating unskilled, skilled, equivalent to A-level qualification, and university degree. We included three EGP classes (professionals, routine non-manual workers and workers) as done with Häuberer, šafr (2008) following Erikson and Goldthorpe (1992) accompanied by a category for "no class indicated" to prevent too many missing values. Employment status was measured by being employed, a pensioner, a homemaker, a student or unemployed. The size of the place of residence was indicated by rural or urban quality. Central demographics are presented in Table 2. In all samples, except the Czech one, more women participated than men. On average, the respondents were between 36 and 43 years old. Concerning education, almost $50 \%$ of Russians and Czechs had at minimum a qualification equivalent to A-level, whereas only $27 \%$ of the Dagestans and $21 \%$ of the Chechens had education at this level.

\section{Table 2. Demographics}




\begin{tabular}{|c|c|c|c|c|}
\hline & $\begin{array}{r}\text { Russian } \\
\text { (Muscovites) }\end{array}$ & Czech & Dagestan & Chechen \\
\hline$N$ & 291 & 129 & 261 & 166 \\
\hline \multicolumn{5}{|l|}{ Gender (\%) } \\
\hline Male & 46 & 53.5 & 38.3 & 42.8 \\
\hline Female & 54 & 46.5 & 61.7 & 57.2 \\
\hline \multicolumn{5}{|l|}{ Age } \\
\hline Mean & 38.50 & 42.61 & 36.43 & 37.67 \\
\hline Median & 38.00 & 43.00 & 35.00 & 37.00 \\
\hline Standard Deviation & 11.796 & 16.307 & 12.095 & 11.970 \\
\hline Range & 42 & 63 & 42 & 41 \\
\hline \multicolumn{5}{|l|}{ Education (\%) } \\
\hline \multicolumn{5}{|l|}{ Low (elementary, } \\
\hline skilled) & 51.9 & 51.2 & 73.2 & 78.9 \\
\hline \multicolumn{5}{|l|}{ High (A-level, } \\
\hline University) & 48.2 & 48.9 & 26.8 & 21.1 \\
\hline
\end{tabular}

Notes: merged data from projects "Social Relationships among Czech Citizens" (Czech Republic 2007/8) and "Values and Economical Behaviour" (Russia 2012)

4.9 For all analyses, we merged the data into a single data set. To obtain an idea of differences in social networks and social capital among the researched groups, we compared the mean values of the network and social capital measures by Student's t-tests using SPSS 19. To evaluate significant differences between percent shares, we used $\Phi$ criterion - Fischer's angular transformation (Gubler \& Genkin 1973). This criterion evaluates the significance of differences between the percentages of two samples in which the effect of interest is registered.

4.10 Because these univariate analyses are not able to control for background variables, we additionally calculated fixed effects models using StataSE 13. We used a fixed effects model, where we expect that the independent variables explain the social capital simultaneously accounting for the network embeddedness of every individual, that is, we account for the interdependence of the independent variables (cf. Snijders \& Bosker 2012). Thus, we included network embeddedness of the respondents in family, friends and voluntary networks as random slope in the models. Furthermore, we included interactions between the network measures and the respondents' cultural background (as suggested with Brambor et al. (2006)), because we expect the effects to differ depending on the cultural background.

\section{Results}

\section{Descriptive Comparisons}

5.1 Social Networks. First, we compared the four groups, Czechs, Russians (Muscovites), Dagestans, and Chechens, according to their network embeddedness. Figure 2 displays the contact frequencies to the family members of the respondents of the four groups, and Table 3 shows the results of the t-tests. Our results demonstrate differences between the cultural groups. The fewest differences can be observed between the responses of Chechens and Dagestans. However, we found many differences between the representatives of traditional cultures (Dagestans and Chechens) and modern cultures (Russian and Czech). Chechens and Dagestans (mostly) have a higher contact frequency with their relatives than Russians and Czechs do. We assumed that Russians (Muscovites) and Czechs would be very similar, but this assumption was not confirmed. However, in general, we can say that Russians (Muscovites) and Czechs have less contact with family members than do Chechens and Dagestans (see Figure 2 and Table 3). 


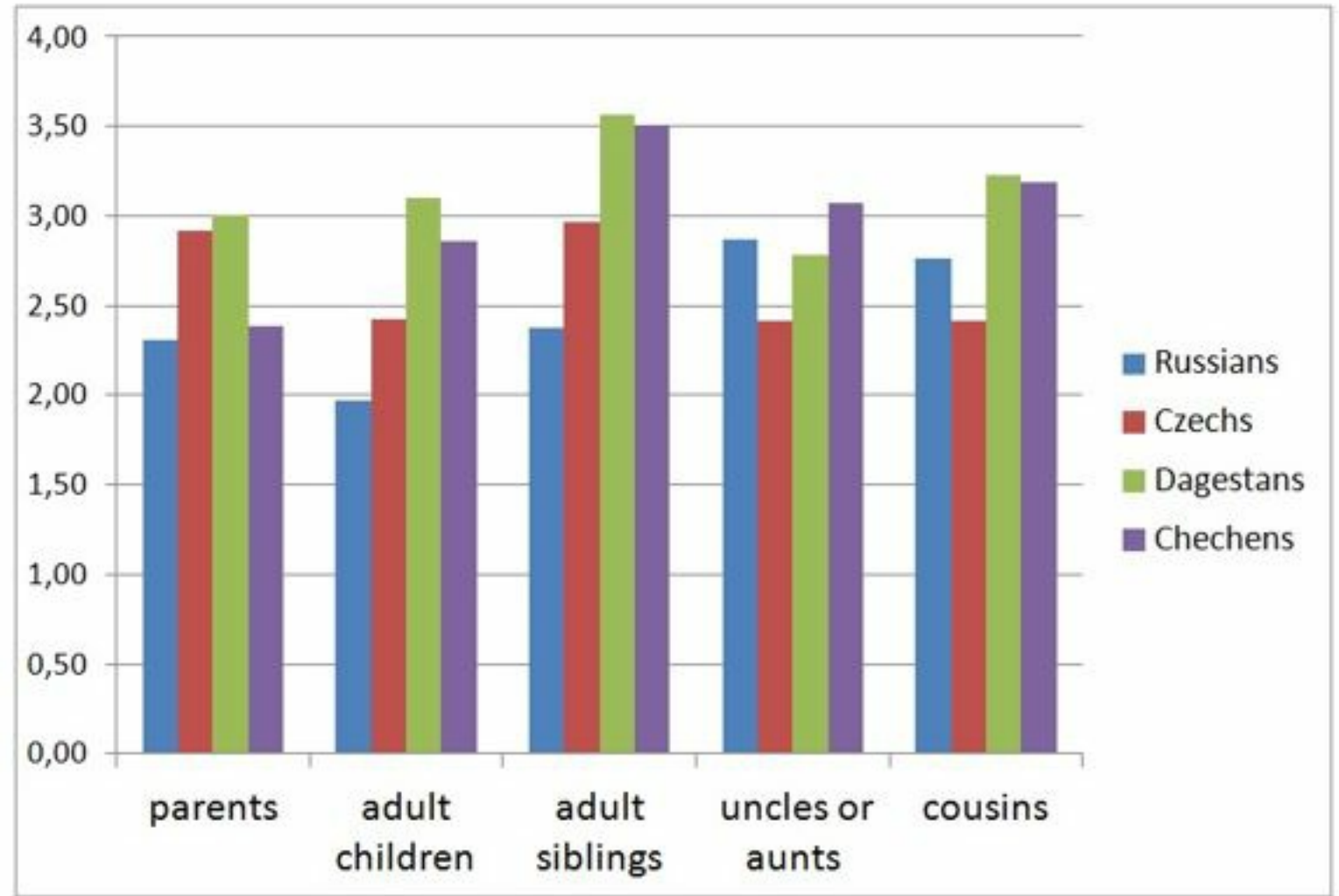

Figure 2. Contact Frequency - Family (mean values)

Notes: merged data from projects "Social Relationships among Czech Citizens" (Czech Republic 2007/8) and

"Values and Economical Behaviour" (Russia 2012); range of the scale from 1 to 4

Table 3. Significance of Intercultural Differences - Frequency of Contacts (Family)

\begin{tabular}{lcccccc}
\hline $\begin{array}{l}\text { How often } \\
\text { you had } \\
\text { contacts... }\end{array}$ & $\begin{array}{c}\mathrm{t} \\
\text { Rus/Cz }\end{array}$ & $\begin{array}{c}\mathrm{t} \\
\text { Rus/Dag }\end{array}$ & $\begin{array}{c}\mathrm{t} \\
\text { Rus/Chech }\end{array}$ & $\begin{array}{c}\mathrm{T} \\
\mathrm{Cz} / \mathrm{Dag}\end{array}$ & $\begin{array}{c}\mathrm{t} \\
\mathrm{Cz} / \text { Chech }\end{array}$ & $\begin{array}{c}\mathrm{t} \\
\mathrm{Dag} / \text { Chech }\end{array}$ \\
\hline Parents & $-3.54^{* * *}$ & $-4.18^{* * *}$ & -0.41 & -0.46 & $2,71^{* *}$ & $3.21^{* * *}$ \\
Adult children & $-2.58^{*}$ & $-7.17^{* * *}$ & $-4.95^{* * *}$ & $-3.65^{* * *}$ & $-2.07^{*}$ & 1.35 \\
Adult siblings & $-3.98^{* * *}$ & $-9.13^{* * *}$ & $-8.98^{* * *}$ & $-3.38^{* * *}$ & $-4.09^{* * *}$ & 0.49 \\
Uncles or & $3.87^{* * *}$ & 0.69 & -1.07 & $-2.67^{* *}$ & $-5.11^{* * *}$ & $-2.12^{*}$ \\
aunts & & & & & & \\
Cousins & $3.0^{* *}$ & $-4.37^{* * *}$ & $-3.62^{* * *}$ & $-6.96^{* * *}$ & $-6.09^{* * * *}$ & 0.28 \\
& & & & & & \\
\hline
\end{tabular}

Notes: merged data from projects "Social Relationships among Czech Citizens" (Czech Republic 2007/8) and "Values and Economical Behaviour" (Russia 2012); Student's t-test (t); $\mathrm{N}=847 ;{ }^{* \star *} \mathrm{p}<0.001,{ }^{* *} \mathrm{p}<0.01,{ }^{*} \mathrm{p}<0.05$.

5.2 Figure 3 and Table 4 present the comparative analysis results of the number of friends of the four cultural group respondents. The greatest differences appear regarding the number of friends other than colleagues, neighbors and family members. Czechs demonstrate the greatest number of friends in all three categories, whereas Chechens have the lowest number of friends among colleagues and other friends. However, we do not find a clear pattern of network composition caused by cultural background. First, Czechs do not have significantly more friends among colleagues and neighbors than do Dagestans. Second, Russians (Muscovites) have fewer friends among their neighbors than Dagestans and Chechens do. 


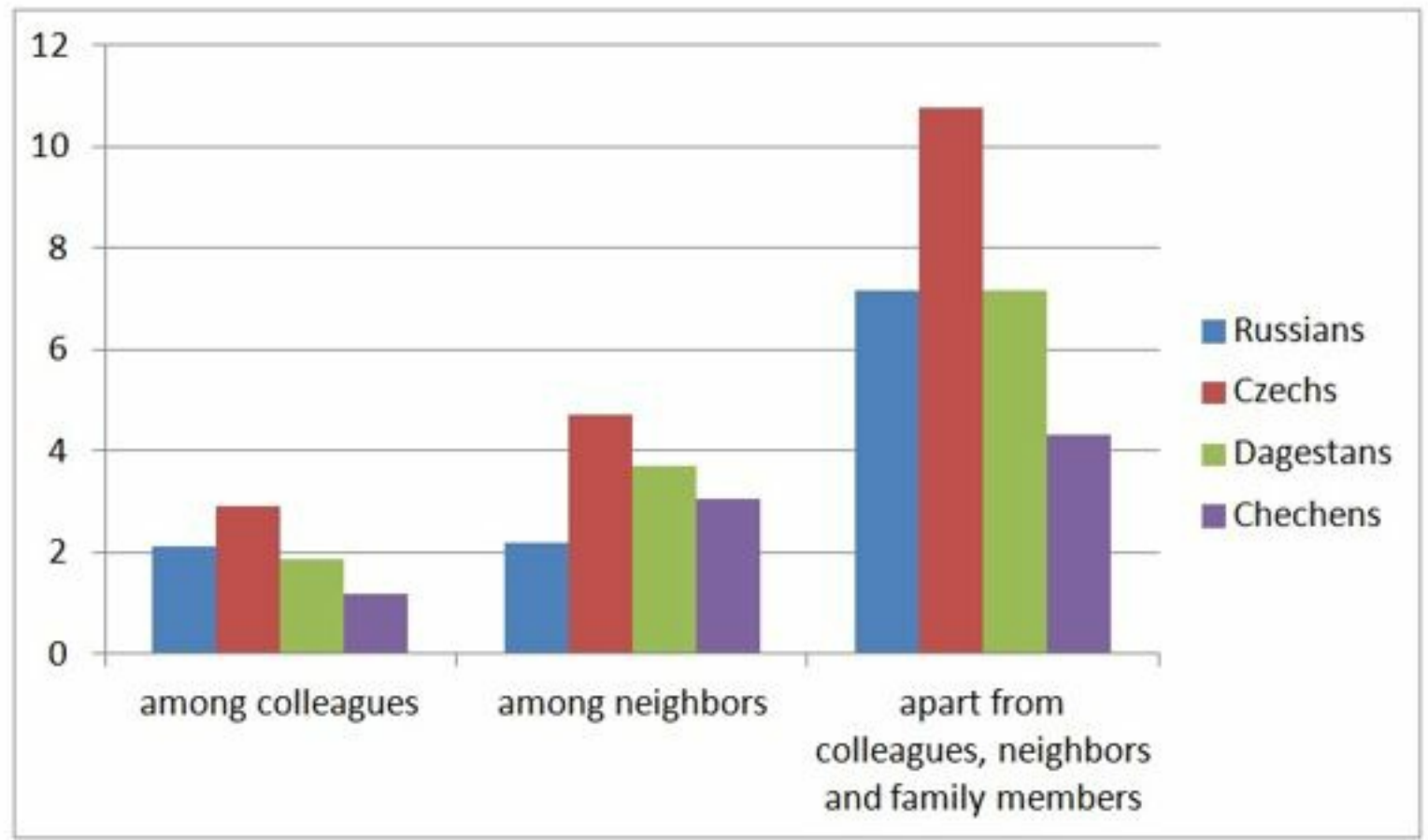

Figure 3. Number of Friends (mean values)

Notes: merged data from projects "Social Relationships among Czech Citizens" (Czech Republic 2007/8) and "Values and Economical Behaviour" (Russia 2012)

Table 4. Intercultural Differences - Number of Friends

\begin{tabular}{|c|c|c|c|c|c|c|}
\hline Number of friends... & $\begin{array}{c}\mathrm{t} \\
\mathrm{Rus} / \mathrm{Cz}\end{array}$ & $\begin{array}{c}\mathrm{t} \\
\text { Rus/Dag }\end{array}$ & $\begin{array}{c}\mathrm{t} \\
\text { Rus/Chech }\end{array}$ & $\begin{array}{c}\mathrm{t} \\
\mathrm{Cz} / \mathrm{Dag}\end{array}$ & $\begin{array}{c}\mathrm{t} \\
\mathrm{Cz} / \mathrm{Chech}\end{array}$ & $\begin{array}{c}\mathrm{t} \\
\text { Dag/Chech }\end{array}$ \\
\hline ... among colleagues & -1.12 & 0.48 & $2.4 * *$ & 1.29 & $3.45^{*}$ & 1,27 \\
\hline ... among neighbors & $-3.01 * *$ & $-2.94 * *$ & $-2.02 *$ & 1,08 & 1.86 & 1.09 \\
\hline $\begin{array}{l}\text {... apart from colleagues, } \\
\text { neighbors, } \\
\text { and family members }\end{array}$ & $-2.61^{* *}$ & -0.003 & $2.7 * *$ & $2.54^{*}$ & $4,98^{* * *}$ & $2.46^{*}$ \\
\hline
\end{tabular}

Notes: merged data from projects "Social Relationships among Czech Citizens" (Czech Republic 2007/8) and "Values and Economical Behaviour" (Russia 2012); Student's t-test (t); N = 847; ${ }^{* \star} p<0.001,{ }^{* *} p<0.01,{ }^{*} p<0.05$.

5.3 Finally, Figure 4 and Table 5 display the differences in participation in voluntary associations of the respondents of the four groups. To evaluate the significance in the differences of the respondents' answers to this question, the criterion $\Phi$ (Fischer's angular transformation) was used. Our results indicate that more representatives of post-modernized societies are active in sports and interest organizations than representatives of traditional cultures. A greater proportion of Russians (Muscovites) are involved in all other associational types than Czechs, Chechens and Dagestans. The associational participation rates among Czechs are rather similar to the participation rates of Chechens and Dagestans. The more active participation of Russian respondents of the Moscow region in activities of political parties, trade unions and non-profit organizations indicates that their social activity is higher. 


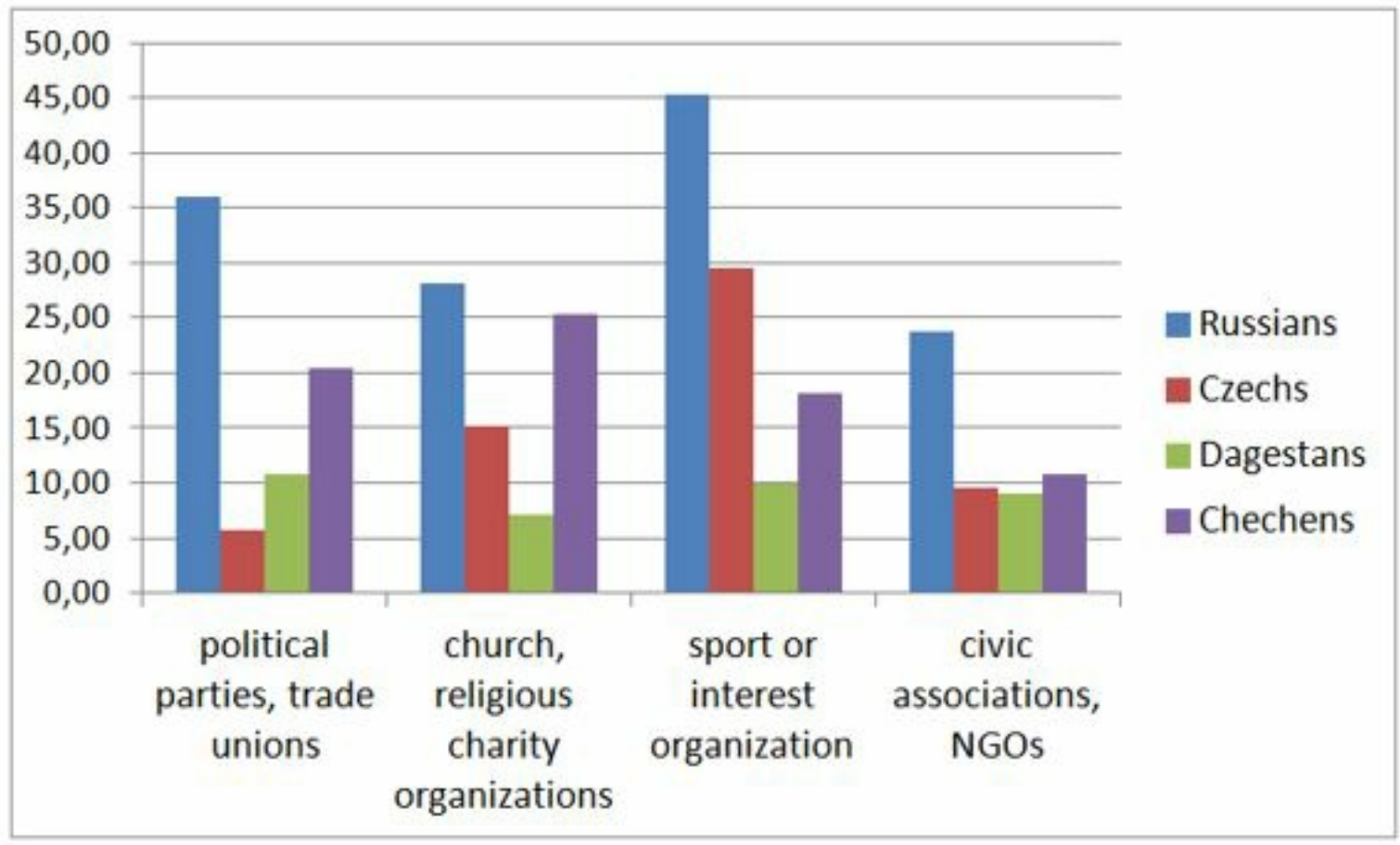

Figure 4. Participation in Associations (\%)

Notes: merged data from projects "Social Relationships among Czech Citizens" (Czech Republic 2007/8) and "Values and Economical Behaviour" (Russia 2012)

Table 5. Intercultural Differences - Participation in Associations

\begin{tabular}{lcccccc}
\hline $\begin{array}{l}\text { How often do you participate in } \\
\text { the activities of... }\end{array}$ & $\begin{array}{c}\varphi \\
\text { Rus/Cz }\end{array}$ & $\begin{array}{c}\varphi \\
\text { Rus/Dag }\end{array}$ & $\begin{array}{c}\varphi \\
\text { Rus/Che }\end{array}$ & $\begin{array}{c}\varphi \\
\mathrm{Cz} / \mathrm{Dag}\end{array}$ & $\begin{array}{c}\varphi \\
\mathrm{Cz} / \mathrm{Che}\end{array}$ & $\begin{array}{c}\varphi \\
\mathrm{Dag} / \mathrm{Che}\end{array}$ \\
\hline $\begin{array}{l}\text {..political parties, trade unions or } \\
\text { prof. assoc. (\%) }\end{array}$ & $6.2^{* * *}$ & $4.9^{* *}$ & $2.5^{* *}$ & 1.4 & $2.8^{* *}$ & $1.9^{*}$ \\
$\begin{array}{l}\text {..church, religious, charity } \\
\text { organizations (\%) }\end{array}$ & $2.4^{*}$ & $4.5^{* *}$ & 0.4 & $1.9^{*}$ & $1.7^{*}$ & $3.5^{*}$ \\
$\begin{array}{l}\text {-. sport or interest organization } \\
\text { (\%) }\end{array}$ & $2.6^{* *}$ & $6.6^{* * *}$ & $4.3^{* *}$ & $3.7^{* *}$ & $1.8^{*}$ & 1.6 \\
$\ldots$ civic associations, NGOs (\%) & $3.02^{* *}$ & $3.2^{* *}$ & $2.5^{* *}$ & 0.13 & 0.3 & 0.4 \\
\hline
\end{tabular}

Notes: merged data from projects "Social Relationships among Czech Citizens" (Czech Republic 2007/8) and "Values and Economical Behaviour" (Russia 2012); $\phi$ (Fischer's angular transformation); $\mathrm{N}=847 ;{ }^{* \star *} \mathrm{p}<0.001$, ${ }^{* *} p<0.01,{ }^{*} p<0.05$.

5.4 Social Capital. In a second step, we compared the social capital access of the four analyzed groups.

Figure 5 and Table 6 show the differences in the social capital access of the respondents by kinship. We do not find a clear pattern of differences between North Caucasus traditional peoples and European post-modernized Slavic peoples. This finding supports Hypothesis $2 \mathrm{a}$, which suggests that individuals living in traditional and in post-modernized societies equally access social capital in their families. However, the two cultural groups seem to be most similar in their access to social capital. Some exceptions occur: Czechs have a larger number of individuals in their networks that are able to help them to find a job than the other researched groups. Russians (Muscovites) access a higher amount of social capital with regard to high income in comparison with Czechs, Chechens and Dagestans. Chechens and Dagestans differ in their access to two social capital indicators only (see Table 6). 


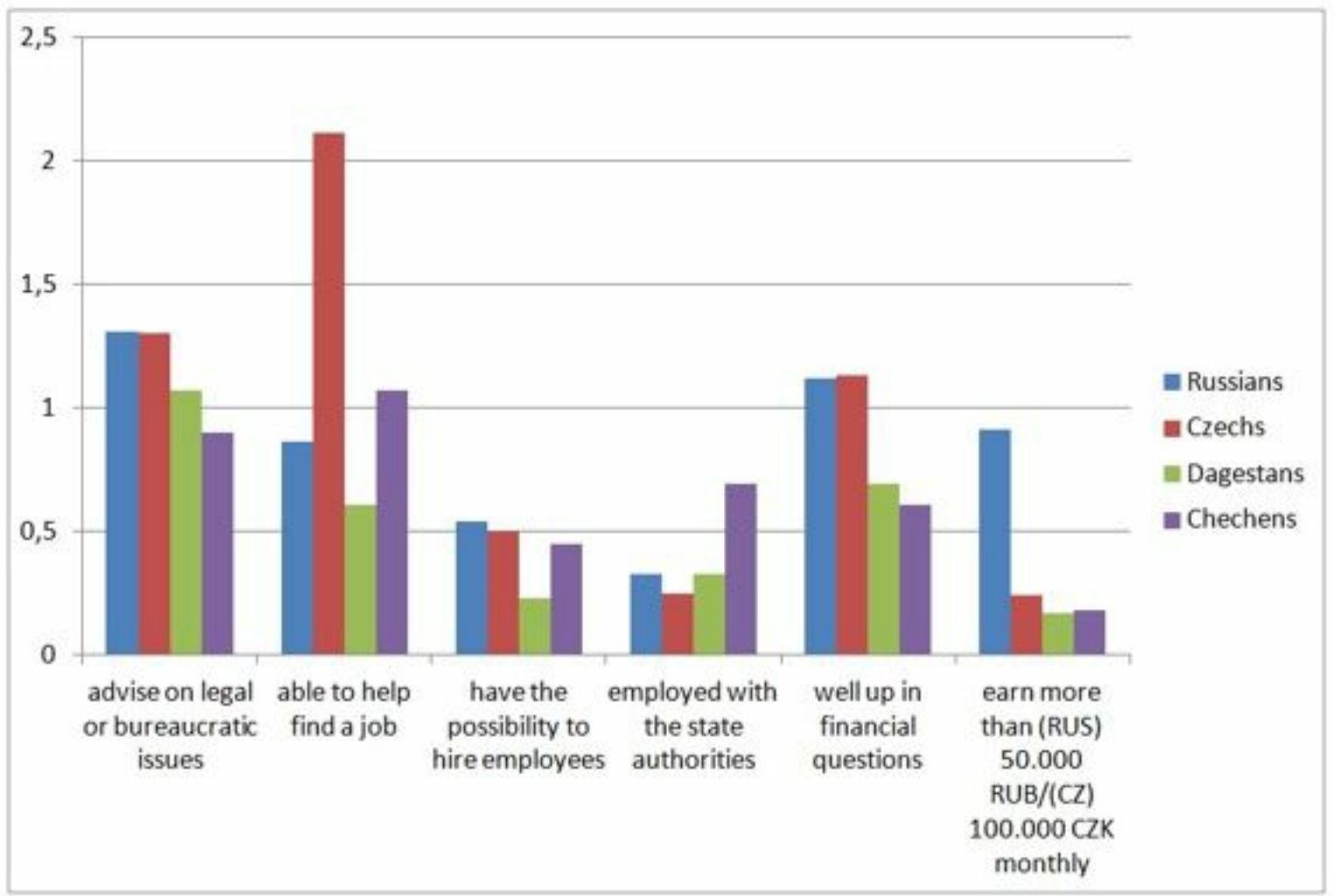

Figure 5. Resources Attained from Family (mean values)

Notes: merged data from projects "Social Relationships among Czech Citizens" (Czech Republic 2007/8) and "Values and Economical Behaviour" (Russia 2012)

Table 6. Intercultural Differences - Resources Attained from Family

\begin{tabular}{|c|c|c|c|c|c|c|}
\hline $\begin{array}{l}\text { How many members of your } \\
\text { family... }\end{array}$ & $\begin{array}{c}\mathrm{t} \\
\mathrm{Rus} / \mathrm{Cz}\end{array}$ & $\begin{array}{c}\mathrm{t} \\
\text { Rus/Dag }\end{array}$ & $\begin{array}{c}\mathrm{t} \\
\mathrm{Rus} / \mathrm{Che} \\
\mathrm{ch}\end{array}$ & $\begin{array}{c}\mathrm{t} \\
\mathrm{Cz} / \mathrm{Dag}\end{array}$ & $\begin{array}{c}\mathrm{t} \\
\mathrm{Cz} \\
/ \text { Chech }\end{array}$ & $\begin{array}{c}\mathrm{t} \\
\mathrm{Dag} / \mathrm{Che} \\
\mathrm{ch}\end{array}$ \\
\hline $\begin{array}{r}\text {...can advise you on legal or } \\
\text { bureaucratic issues }\end{array}$ & 0.07 & 1.18 & $2.6^{* *}$ & 0.98 & $2.08^{*}$ & 0.93 \\
\hline $\begin{array}{r}\text { will be able to help you find } \\
\text { a job? }\end{array}$ & $-3.71^{* * *}$ & 1.08 & -0.80 & $4.51^{* * * *}$ & $2.61^{* *}$ & 1.08 \\
\hline $\begin{array}{r}\text { have the possibility to hire } \\
\text { employees? }\end{array}$ & 0.31 & $3.01^{* *}$ & 0.89 & $2.42^{*}$ & 0.50 & $-2.0^{*}$ \\
\hline $\begin{array}{r}\text {... are employed with the state } \\
\text { authorities? }\end{array}$ & 1.1 & -0.24 & $-3.91^{* * *}$ & -0.93 & $-5.35^{* * *}$ & $-3.5 * * *$ \\
\hline $\begin{array}{r}\text {... are knowledgeable about } \\
\text { financial questions? }\end{array}$ & 0.12 & $2.45^{*}$ & $3.72^{* * * *}$ & $2.64^{* *}$ & $4.1^{* * *}$ & 0.53 \\
\hline ... earn more than (RUS) & $5.53^{* * *}$ & $6.62^{* * *}$ & $6.94^{* * *}$ & 0.71 & 0.61 & -0.13 \\
\hline $\begin{array}{r}50.000 \mathrm{RUB} /(\mathrm{CZ}) 100.000 \mathrm{CZK} \\
\text { monthly? }\end{array}$ & & & & & & \\
\hline
\end{tabular}

Notes: merged data from projects "Social Relationships among Czech Citizens" (Czech Republic 2007/8) and "Values and Economical Behaviour" (Russia 2012); Student's t-test (t); $N=847 ;{ }^{* * *} p<0.001,{ }^{* *} p<0.01,{ }^{*} p<0.05$.

5.5 Figure 6 and Table 7 show social capital obtained from friends. According to these results, post-

modernized Slavic cultures have more social capital than the North Caucasus traditional cultures. Therefore, 
Hypothesis H2b was supported. In addition, we can see that Russians (Muscovites) and Czechs access similar amounts of social capital. We can find the same tendency in the case of Chechens and Dagestans.

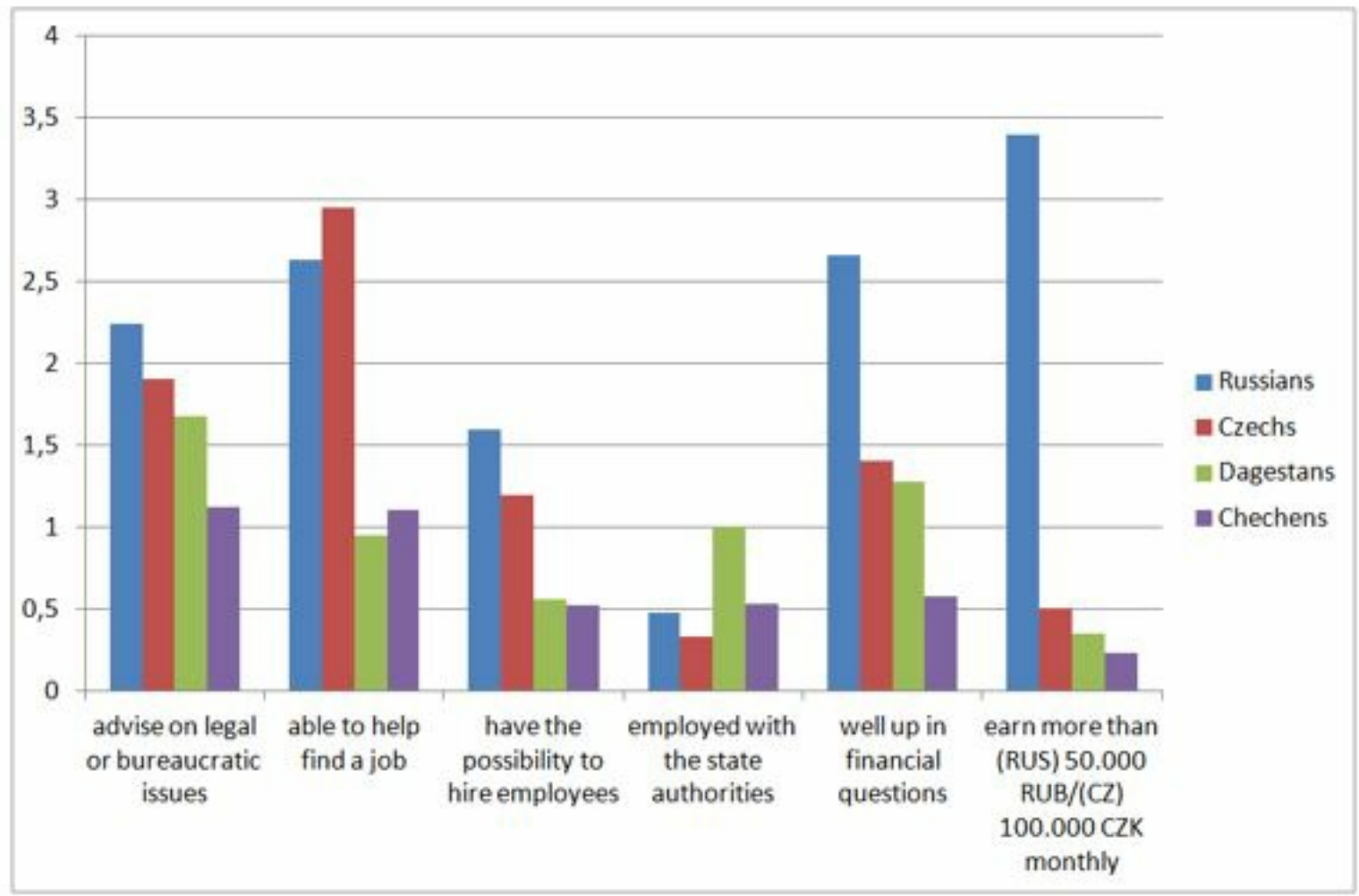

Figure 6. Resources Attained from Friends (mean values)

Notes: merged data from projects "Social Relationships among Czech Citizens" (Czech Republic 2007/8) and "Values and Economical Behaviour" (Russia 2012)

Table 7. Intercultural Differences - Resources Attained from Friends

\begin{tabular}{|c|c|c|c|c|c|c|}
\hline How many of your & $\mathrm{t}$ & $\mathrm{t}$ & $\mathrm{t}$ & $\mathrm{t}$ & $\mathrm{t}$ & $\mathrm{t}$ \\
\hline friends... & $\mathrm{Rus} / \mathrm{Cz}$ & Rus/Dag & Rus/Chech & $\mathrm{Cz} / \mathrm{Dag}$ & $\begin{array}{c}\mathrm{Cz} \\
/ \text { Chech }\end{array}$ & Dag/Chech \\
\hline $\begin{array}{l}\text {... can advise you on legal } \\
\text { or bureaucratic issues? }\end{array}$ & 0.84 & 1.6 & $3.99^{* * *}$ & 0.46 & $1.9^{*}$ & 1.62 \\
\hline $\begin{array}{l}\text {... will be able to help you } \\
\text { find a job? }\end{array}$ & -0.52 & $3.35^{* * *}$ & $3.16^{* 8}$ & $4.25^{* * *}$ & $4.09 * * *$ & -0.50 \\
\hline $\begin{array}{l}\ldots \text { have the possibility to } \\
\text { hire employees? }\end{array}$ & 1.56 & $4.41^{* * *}$ & $4.92^{* * *}$ & $2.82^{* *}$ & $3.25^{* * *}$ & 0.23 \\
\hline $\begin{array}{l}\ldots \text { are employed with the } \\
\text { state authorities? }\end{array}$ & 1.35 & -1.01 & -0.39 & -1.41 & -1.66 & 0.98 \\
\hline $\begin{array}{l}\ldots \text { are knowledgeable about } \\
\text { financial questions? }\end{array}$ & 1.86 & 1.81 & $3.12^{* 8}$ & 0.28 & $3.72^{* * *}$ & 1.69 \\
\hline $\begin{array}{l}\ldots \text { earn more than (RUS) } \\
50.000 \mathrm{RUB} /(\mathrm{CZ}) 100.000\end{array}$ & $9.85^{* * *}$ & $7.57^{* * *}$ & $8.2^{* * *}$ & 0.77 & 1.08 & 0.82 \\
\hline CZK monthly? & & & & & & \\
\hline
\end{tabular}

Notes: merged data from projects "Social Relationships among Czech Citizens" (Czech Republic 2007/8) and

"Values and Economical Behaviour" (Russia 2012); Kolmogorov-Smirnov test (Z); N = 847; *** $<0.001$, ${ }^{* *} \mathrm{p}<0.01,{ }^{*} \mathrm{p}<0.05$. 
Summary. So far, our study indicates differences between post-modern and traditional cultures regarding the contact frequency to family members but no differences regarding the social capital accessed by the family. Regarding the friendship network and participation in voluntary associations, we find no clear pattern regarding cultural background. Czechs have more friends in comparison to Russians (Muscovites) and Chechens. Russians (Muscovites) are more active in voluntary associations than individuals of all other groups, and social capital access by friends is higher in the post-modernized Slavic groups. Thus far, the analyses have not allowed us to account for respondents' characteristics to analyze the effects of cultural group and network embeddedness on social capital access. It will be conducted in the next part.

\section{Multivariate Results}

5.7 In a third step, we calculated fixed effects regressions to test our hypotheses while controlling for the interdependence of the social network embeddedness of individuals. Our results are displayed in Table 8. The results show that social capital access is well explained by network embeddedness, although not always as expected. Individuals who are frequently in contact with family members access less social capital among their families than do individuals with less family contact. Although this result speaks for rejecting Hypothesis $\mathrm{H} 1$, our analyses reveal that the cultural background seems important. In general Russians (Muscovites) access more social capital in their families than do Dagestans, Chechens and Czechs. However, if the Russians (Muscovites) are not in contact with their families, they access less social capital than Dagestans, Chechens and Czechs. Accordingly, Hypothesis $\mathrm{H} 1$ is partly supported. The similarity of Czechs in their social capital access to Dagestans and Chechens indicates that we cannot distinguish between traditional and post-modernized groups. This result partly supports Hypothesis $\mathrm{H} 2 \mathrm{a}$ and shows that, although family networks look different in traditional and post-modernized groups, they still seem to fulfill similar functions (see also Höllinger \& Haller 1990). This also implies that individuals migrating from traditional to modernized societies are capable to access similar amounts of social resources also if they hold different values regarding their family than individuals of their country of destination. Accordingly, traditional values shall not be an obstacle to social integration. The great advantage of Russians (Muscovites) in social capital access from family may be caused by the types of resources we asked for. We included only resources useful for instrumental action, which are according to Lin (2001) accessible through weak ties. Families, however, are mostly composed of strong ties and are more likely to provide resources useful for expressive action. This means that Russians (Muscovites) even dispose of social resources useful for instrumental action in their families. Accordingly, one could expect them to be more successful in status attainment than individuals from Chechenya, Dagestan and Czech Republic.

5.8 Regarding social capital from friends, Hypothesis $\mathrm{H} 1$ is clearly supported by the findings. Individuals with large friendship networks and who participate in voluntary associations access more social capital in their friend networks than individuals with smaller friendship networks and who participate less. Cultural background also seems to play a moderate role. In comparison to Russians (Muscovites), Dagestans, Chechens and Czechs access less social capital among their friends even when controlling for the friend network size. Russians (Muscovites) who participate in voluntary associations only differ from Chechens in their social capital access from friends. Thus, Hypothesis H2b is also partly supported. The post-modernized context only leads to higher social capital access in the friends network for Russians (Muscovites) in comparison to Dagestans and Chechens but not for Czechs, who also represent a post-modernized society. The "extra-family" orientation becomes evident only for Russians (Muscovites). Again Russians (Muscovites) seem to be advantaged in social capital access from friends and thus in their possible status attainment. Accordingly, Russians (Muscovites) have a resource potential which allows them to take an advantageous position in the society. Otherwise, traditional values do not seem an obstacle to access social capital in friendship networks. Accordingly, societal integration provided by integration in social networks shall be no problem for individuals migrating from traditional to modernized societies.

Table 8. Fixed Effects Regressions: Determinants of Social Capital Access 


\begin{tabular}{|c|c|c|c|c|}
\hline & \multicolumn{2}{|c|}{$\begin{array}{c}\text { Social Capital among } \\
\text { Family }\end{array}$} & \multicolumn{2}{|c|}{$\begin{array}{c}\text { Social Capital among } \\
\text { Friends }\end{array}$} \\
\hline & $\mathrm{b}$ & Std. error & $\mathrm{b}$ & Std. error \\
\hline \multicolumn{5}{|l|}{ Fixed Effects } \\
\hline Contact family & $-.151^{* 4}$ & .056 & $-.166^{44}$ & .048 \\
\hline Friendship network & .186 & .101 & $.724^{4+4}$ & .089 \\
\hline Participation in voluntary associations & .270 & .167 & $.370^{4 *}$ & .127 \\
\hline \multicolumn{5}{|l|}{ Cultural group (ref. Russian) } \\
\hline Dagestan & $-1.412^{4 * 4}$ & .351 & $-1.139^{444}$ & .310 \\
\hline Chechen & $-1.397^{444}$ & .391 & $-1.250^{4 * 4}$ & .348 \\
\hline Czech & $-1.093^{4 *}$ & .341 & $-.945^{444}$ & .298 \\
\hline \multicolumn{5}{|l|}{ Interactions (ref. Russian) } \\
\hline Dagestan x Contact family & $311^{444}$ & .089 & $.212^{* 4}$ & .078 \\
\hline Dagestan x Friendship network & .103 & .135 & $-.330^{4 *}$ & .123 \\
\hline Dagestan $\mathrm{x}$ Participation in voluntary associations & .474 & .343 & -.238 & .249 \\
\hline Chechen $\mathrm{x}$ Contact family & $396^{44}$ & .102 & $.253^{* 4}$ & .090 \\
\hline Chechen $\mathrm{x}$ Friendship network & -.128 & .158 & $-.436^{4 *}$ & .144 \\
\hline Chechen $\mathrm{x}$ Participation in voluntary associations & -356 & .297 & $-.532^{*}$ & .219 \\
\hline Czech x Contact family & $338^{* 44}$ & .100 & $.178^{*}$ & .087 \\
\hline Czech $\mathrm{x}$ Friendship network & -.062 & .133 & $-.556^{44 *}$ & .121 \\
\hline \multirow{2}{*}{\multicolumn{5}{|c|}{ Control variables }} \\
\hline & & & & \\
\hline Sex (female) & .001 & .063 & $-.190^{44 *}$ & .055 \\
\hline Age & .003 & .004 & .000 & .003 \\
\hline Education ( $\min$. A-level) & .107 & .065 & .106 & .057 \\
\hline \multicolumn{5}{|l|}{ EGP classes (ref. Professionals) } \\
\hline Routine non-manual workers & $-.269^{* *}$ & .092 & -.101 & .080 \\
\hline Workers & -.176 & .098 & -.059 & .085 \\
\hline No class specified & -.243 & .377 & -.246 & .344 \\
\hline \multicolumn{5}{|l|}{ Employment status (ref. employed) } \\
\hline Pensioner & .099 & .380 & -.007 & .347 \\
\hline Homemaker & .180 & .378 & .219 & .345 \\
\hline Student & .423 & .424 & .254 & 384 \\
\hline Unemployed & .048 & .380 & .112 & .347 \\
\hline Place of residence (rural) & -.108 & .074 & -.084 & .065 \\
\hline Intercept & .374 & .268 & $.923^{4+4}$ & .232 \\
\hline \multicolumn{5}{|l|}{ Random effects } \\
\hline \multicolumn{5}{|l|}{ ID: identity } \\
\hline Variance (Contact family) & $.000^{4 * 4}$ & .000 & $.000^{44 *}$ & .000 \\
\hline Variance (Friendship network) & $.177^{444}$ & .038 & $.185^{444}$ & .026 \\
\hline Variance (Participation in voluntary association) & $.553^{*}$ & .143 & $.141^{44 *}$ & .072 \\
\hline Variance (Intercept) & .174 & .830 & .140 & 5.132 \\
\hline Variance (Residual) & .038 & .830 & .027 & 5.132 \\
\hline $\mathrm{R}^{2}$ & 235 & & .447 & \\
\hline
\end{tabular}

Source: merged data from projects "Social Relationships among Czech Citizens" (Czech Republic 2007/8) and "Values and Economical Behaviour" (Russia 2012), N=438, ${ }^{*} p<0.05,{ }^{* *} p<0.01,{ }^{* * *} p<0.001$

\section{Limitations of the Study}

6.1 One limitation of our study is that we asked for social resources with rather financial and prestigious focus only. Thus, personal support resources were neglected. However, these resources are very relevant in cohesive networks like families. One can suppose that the access to personal support social capital differs also between traditional and post-modernized societies, as the latter have more means to replace, for example, personal care by a welfare state institution. Besides the limitation of social resource measures, our data does not allow us to further investigate the reasons why our respondents vary in their contact frequency to relatives or friends. Here especially qualitative methods would have been useful as they are capable of analyzing mechanisms of resource transfer in detail. Thus, we recommend using a mixed methods approach for future studies.

6.2 Another limitation lies in the design of our research including representatives of three ethnic groups that differ in their level of cultural modernization but living in one and the same country. Respondent's belongings to one country can reduce the level of intercultural differences among the ethnic groups. However, this design allowed us to reduce cross-country differences between ethnic groups. Furthermore, the inclusion of the Czech sample added intercultural differences in our study. Czechs are a Slavic group like Russians and have close cultural values and a close level of modernization to Russians. This allowed us to analyze both, the similarity of ethnic groups that are close by values and that are close by level of cultural modernization. By and large it is 


\section{Conclusions}

We analyzed the impact of cultural background and social values on social network composition and access to social capital (i.e. social resources). We assume that according to Inglehart \& Welzel's (2010) cultural map, a significant difference exists between post-modernized cultures that hold secular-rational values paired with self-expression values and traditional cultures that hold traditional and survival values. Whereas the former tend to have small families but large friendship networks and participate in voluntary associations, the latter have extensive families and small extra-family networks. However, the importance of family remains the same in traditional and post-modernized societies. Accordingly, we expected traditional and post-modernized societies to access similar amounts of social capital in their families and post-modernized societies to access more social capital in their extra-family networks than traditional societies. To test these assumptions, we analyzed Czech and Russian survey data including four groups - Czechs, Russians from Moscow, Dagestans and Chechens. According to the cultural map, our theoretical considerations and empirical results, Czechs and Russians (Muscovites) represent post-modernized Slavic cultures, and Dagestans and Chechens represent traditional North Caucasus cultures.

7.2 Our descriptive results regarding contact frequency with family members indicate that North Caucasus traditional peoples (Chechens and Dagestans) are very similar to each other and differ from European postmodernized Slavic peoples (Russians and Czechs). However, we do not find a clear pattern of friendship network composition caused by cultural background. In this case, Czechs have more friends among colleagues, neighbors and others than Russians (Muscovites), Chechens and Dagestans do. With respect to formal network embeddedness (organizations, associations), we find many differences between the studied groups, but we cannot argue that these differences are related to the mentioned dichotomy between post-modernized Slavic peoples and traditional North Caucasus peoples. Russians (Muscovites) participate in associations more often than Czechs, Chechens, and Dagestans do.

7.3 As expected, we did not find clear differences regarding the social capital attained from the family network between the post-modernized and traditional groups. Access to social capital from friends has a clear pattern of differences between post-modernized Slavic peoples and traditional North Caucasus peoples. Czechs and Russians (Muscovites) have more social capital from friends than Chechens and Dagestans do.

7.4 Our multivariate results reveal the interrelations between social network embeddedness and social capital access while controlling for other influencing factors. Regarding the influence of network embeddedness on social capital access, we find a context effect for the friendship network: the size of the network of friends as well as participation in voluntary associations predicts social capital access among friends. This finding is in line with study results of Häuberer (2014) or Finsveen \& van Oorschot (2008) who showed that number of friends and associational involvement determine social capital access. It seems that members of associations are seen as friends or as sources of social resources. In contrast, contact to family members seems to decrease social capital access by family. This might be explained by the instrumental resources we asked for in the surveys. Families as representatives of strong ties are known to provide resources rather useful for expressive action (cf. Lin 2001).

7.5 Further, the results indicate that cultural background does not play such a crucial role for social capital access through the family or friends. In both cases Dagestans, Chechens and Czechs access significantly less social capital than Russians (Muscovites) do, but only if Russians (Muscovites) are in frequent contact with their families or have big friendship networks. That Czechs do not differ significantly from Dagestans and Chechens indicates that social resources are transferred in the family in both traditional and post-modernized societies, although this transfer may have different directions (cf. Hofferth \& Iceland 1998). It is thinkable, that stability of family relations in post-modern societies, which are less family-oriented than traditional societies, is secured by means of communication and infrastructure (cf. Litwak \& Szelenyi 1969). Accordingly, families in both contexts realize the same amount of social capital transfer. In general, we found that the Russians (Muscovites) are advantaged in social capital access. Accordingly, we can expect that they benefit from social capital access and are able to reach higher status positions in society. This gains relevance when thinking about the topic of exclusion provided by social capital in Bourdieu's reasoning. Accordingly, it seems Russians (Muscovites) have the capacity to distinguish themselves from fellow citizens in the Russian Federation by their higher social capital access. 
stages of the modernization process has broad prospects. This study is also significant because more and more people migrate from traditional cultures to the modernized and developed cultures, because of economic reasons or because they are war-affected. Accordingly, the better we know the different characteristics of traditional and modern cultures in comparative perspective (including social capital), the better we will be able to manage the processes of social integration. Our results indicate that migrants shall not face obstacles in social capital access because of their social value orientation. Also if their value orientations cause different network compositions than the network compositions of citizens of the destination country, the networks contain the same potential for granting social capital. And the access to social capital allows migrants to gain societally valued positions.

\section{Appendix}

Download Supplementary information here

\section{Acknowledgements}

The work of Julia Häuberer was supported by the Universität Hamburg. The Czech survey was financed by the Grant Agency of the Charles University in Prague, Czech Republic (GAUK Project no. 126507).

The work of Alexander Tatarko (the Russian part of the study) was prepared within the framework of the Basic Research Program at the National Research University Higher School of Economics (HSE) and supported within the framework of a subsidy granted to the HSE by the Government of the Russian Federation for the implementation of the Global Competitiveness Program.

\section{Notes}

Corresponding author currently at Faculty of Business Administration, Economics and Social Science; Universität Hamburg, Welckerstraße 8, 20354 Hamburg, Tel: +49(0)40-42838-8658; E-mail-address: julia.haeuberer@wiso.uni-hamburg.de.

Because Moscow is one of the most developed regions in Russia, we expect the values of the Russians in our sample to differ from the rest of Russia.

Here we analyzed the respondents that participated in the test and the retest. The original sample included 400 respondents.

\section{References}

ALLIK J and Realo A (2004) 'Individualism-Collectivism and Social Capital', Journal of Cross-Cultural Psychology, Vol. 35, p. 29-49.

BEHTOUI A (2007) 'The Distribution and Return of Social Capital: Evidence from Sweden',European Societies, Vol. 9, p. 383-407. [doi:10.1080/14616690701314093]

BEILMANN M and Realo A (2012) 'Individualism-collectivism and social capital at the individual level', Trams, Vol. 16, p. 205-217.

BERRY J W, Poortinga Y H and Pandey J (Eds.) (1997) Handbook of cross-cultural psychology. Vol. 1. Theory and method, Boston, Allyn \& Bacon.

BOURDIEU P (1986) 'The Forms of Capital', In: Richardson J G (Ed.)Handbook of theory and research for the sociology of education, New York, Greenwood, p. 241-258. 
BRAMBOR T, Clark W R and Golder M (2006) 'Understanding Interaction Models: Improving Empirical Analyses', Political Analysis, Vol. 14, p. 63-82.

BURT R S (2000) 'The Network Structure of Social Capital', Research in Organizational Behaviour, Vol. 22, p. 345-423.

CAUCASUS ONLINE (2012) V Chechne nabljudaetsja vysokaja stepen' religioznoj neterpimosti(There is a high degree of religious intolerance In Chechnya). Online http://kavkasia.net/Russia/2012/1338338610.php, downloaded 17th January, 2014.

COLEMAN J S (1988) 'Social Capital in the Creation of Human Capital',American Journal of Sociology, Vol. 94, p. $95-120$.

COLEMAN J S (1990) Foundations of Social Theory, Cambridge, Belknap Press. [doi:10.1093/pan/mpi014]

CZECH STATISTICAL OFFICE (2013a) Population by sex, age, marital status and educational attainment, Online http://vdb.czso.cz/sldbvo/en, downloaded 15th October, 2013.

CZECH STATISTICAL OFFICE (2013b) Population by religious belief, municipality size groups and by regions, Online http://vdb.czso.cz/sldbvo/en, downloaded 15th October, 2013.

DE VRIES E (1961) Man in rapid social change, Garden City, New York, Doubleday \& Co..

DRESSLER W W (1982) Hypertension and Culture Change: Acculturation and Disease in the West Indies New York, Redgrave Publishing Company.

DRESSLER W W (1994) Cross-Cultural differences and social influences in social support and cardiovascular disease, New York, Plenum Press, p. 167-192.

ENGSTRöM K, Mattsson F, Järleborg A and Hallqvist J (2008) 'Contextual social capital as a risk factor for poor self-rated health: A multilevel analysis', Social Science \& Medicine 66, p. 2268-2280.

ERIKSON R and Goldthorpe J H (1992) The Constant Flux. A Study of Class Mobility in Industrial Societies Oxford: Clarendon Press.

ESS (2012) European Social Survey6th wave. Online http://www.europeansocialsurvey.org/download.html? file=ess6e02\&y=2012, downloaded 25th May, 2016.

FINSVEEN E and van Oorschot W (2008) 'Access to Resources in Networks: A Theoretical and Empirical Critique of Networks as a Proxy for Social Capital', Acta Sociologica 51, p. 293-307.

FISCHER C S (1982) To dwell among friends: Personal networks in town and city Chicago: University of Chicago Press.

FUKUYAMA F (1995) Trust: The Social Virtues and the Creation of Prosperity. New York, Free Press.

GRANOVETTER M (1973) 'The Strength of Weak Ties', American Journal of Sociology, Vol. 78, p. 1360-1380.

GUBLER E and Genkin A (1973) Primenenie kriteriev neparametricheskoj statistiki dlja ocenki dvuh grupp nabljudenij $v$ mediko-biologicheskih issledovanijah (Application the criteria of non-parametric statistics for the assessment of the two groups of cases in biomedical research), Leningrad: Medicina.

HäUBERER J (2011) Social Capital Theory. Towards a Methodological Foundation. Wiesbaden, VS Verlag für Sozialwissenschaften.

HäUBERER J (2014) 'Social Capital in Voluntary Associations', European Societies, Vol. 16, p. 570-593.

HäUBERER J and šafr J (2008) 'Subjective Social Distance: Interaction Willingness and Occupational Stimuli', In: šafr J and Häuberer J Social Distance and Stratification: Social Space in the Czech Republic. Prague: Sociologický ústav AV čR, p. 21-30.

HOFFERTH S L and Iceland J (1998) 'Social Capital in Rural and Urban Communities', Rural Sociology, Vol. 63, p. 574-598.

HöLLINGER F and Haller M (1990) 'Kinship and social networks in modern societies: A cross-cultural 
comparison among seven nations', European Sociological Review, Vol. 6, p. 103-124.

INGLEHART R (1997) Modernization and postmodernization: Cultural, economic, and political change in 43 societies, Princeton, N.J., Princeton University Press.

INGLEHART R and Baker W (2000) 'Modernization, cultural change, and the persistence of traditional values', American Sociological Review 65: p. 19-50. [doi:10.1016/j.socscimed.2008.01.019]

INGLEHART R and Welzel C (2005) Modernization, Cultural Change and Democracy. Cambride, Cambridge University Press.

INGLEHART R and Welzel C (2010) 'Changing Mass Priorities: The Link between Modernization and Democracy', Perspectives on Politics. Vol. 8, p. 551-567.

INKELES A and Smith D H (1974) Becoming modern, Cambridge, Harvard University Press.

IZVESTIYA (2014) Russians consider themselves to be believers, but do not go to Church(Rossijane schitajut sebja verujushhimi, no v cerkov' ne hodjat), Online [http://izvestia.ru/news/563084;], downloaded $17^{\text {th }}$ January, 2014.

KAWACHI I, Kennedy B P, Kimberly L and Prothrow-Smith D (1997) 'Social Capital, Income Inequality and Mortality', American Journal of Public Health, Vol. 87, p. 1491-1498.

KAWACHI I, Kennedy, B P and Glass R (1999) 'Social Capital and Self-Rated Health: A Contextual Analysis', American Journal of Public Health, Vol. 89, p. 1187-1193.

KOLLMORGEN R (2009) 'Postsozialistische Wohlfahrtsregime in Europa - Teil der "Drei Welten" oder eigener Typus? Ein empirisch gestützter Rekonzeptualisierungsversuch', In: Pfau-Effinger B, Sakac-Magdalenic $\mathrm{S}$ und Wolf C (Hg.): International vergleichende Sozialforschung. Ansätze und Messkonzepte unter den Bedingungen der Globalisierung, Wiesbaden, VS-Verlag, p. 65-92.

LEBEDEVA N and Grigoryan L (2013) 'Implicit theories of innovativeness: cross-cultural analysis', HSE Working paper, Series: Sociology, Online http://www.hse.ru/data/2013/03/02/1293260233/16SOC2013.pdf, downloaded 25th May, 2016.

LIN N (1999) 'Social Networks and Status Attainment', Annual Review of Sociology, Vol. 25, p. 467- 487.

LIN N (2001) Social Capital: A Theory of Social Structure and Action, Cambridge, Cambridge University Press.

LITWAK E and Szelenyi I (1969) 'Primary group structures and their functions: Kin, neighbors, and friends', American Sociological Review, Vol. 34, 465-481.

MOLLENHORST G, Volker B and Flap H (2014) 'Changes in personal relationships: How social contexts affect the emergence and discontinuation of relationships', Social Networks, Vol. 37, p. 65-80. [doi:10.1086/225469]

PAXTON P (2002) 'Social Capital and Democracy: An Interdependent Relationship', American Sociological Review, Vol. 67, p. 254-277.

PIURKO Y, Schwartz S and Davidov, E (2012) 'Basic personal values and the meaning of left-right political orientations in 20 countries', Political Psychology, Vol. 32, p. 537-561.

PLICKERT G, Côté R R and Wellman B (2007) 'It's not who you know, it's how you know them: Who exchanges what with whom?', Social Networks, Vol. 29, p. 405-429.

PUTNAM R D (1994) 'Social Capital and Public Affairs', Bulletin of the American Academy of Arts and Sciences, Vol. 47, p. 5-19.

PUTNAM R D (2000) Bowling Alone: The Collapse and Revival of American Community, New York, Simon Schuster.

RAISER M, Haerpfer Ch, Nowotny T and Wallace C (2001) Social Capital in Transition Countries: A First Look at the Evidence, London, EBRD Working Paper.

RIA-NEWS (2012) Rejting kachestva zhizni v regionah Rossijskoj Federacii(Raiding of the quality of life in the 
regions of the Russian Federation), Online http://vid1.rian.ru/ig/ratings/life_2012.pdf, downloaded 7th January, 2014.

RUSSIAN FEDERAL STATE STATISTICS SERVICE (2010) Chislennost' naselenija sub'ektov Rossijskoj Federacii po administrativno-territorial'nym edinicam (The population of the Russian Federation in different administrative and territorial units), Online http://www.gks.ru/free_doc/new_site/perepis2010/croc/perepis_itogi1612.htm, downloaded 15th October, 2013.

RUSSIAN FEDERAL STATE STATISTICS SERVICE (2013) Gross Domestic Product per capita (GDP, Online http://www.gks.ru/, downloaded 15th October, 2013.

SCHWARTZ S H (2006) 'Basic human values: Theory, measurement, and applications', Revue Française de Sociologie, Vol. 47, p. 249-288.

SCHWARTZ S H (2012) 'An Overview of the Schwartz Theory of Basic Values'.Online Readings in Psychology and Culture, Vol. 2. http://dx.doi.org/10.9707/2307-0919.1116.

SCHWARTZ, S H and Fischer R (2012) 'Whence differences in value priorities? Individual, cultural, or artifactual sources', Journal of Cross-Cultural Psychology, Vol. 42, p. 1127-1144. [doi:10.1093/oxfordjournals.esr.a036553]

SNIJDERS T A B and Bosker R J (2012)Multilevel analysis. An introduction to basic and advanced multilevel modelling, 2. Ed., London, Sage.

VAN DER GAAG M and Snijders T A B (2005) 'The Resource Generator: social capital quantification with concrete items', Social Networks, Vol. 27, p. 1-29.

VERHAEGHE P and Tampubolon G (2012) 'Individual social capital, neighborhood deprivation, and self-rated health in England', Social Science \& Medicine, Vol. 75, p. 349-357.

WORLD BANK (2013a) Urban population (\% of total), Online http://data.worldbank.org/indicator/SP.URB.TOTL.IN.ZS, downloaded 14th August, 2013. [doi:10.2307/2657288]

WORLD BANK (2013b) GDP per capita (current US\$), Online http://data.worldbank.org/indicator/NY.GDP.PCAP.CD, downloaded 14th August, 2013.

YANG K (2007) 'Individual Social Capital and Its Measurement in Social Surveys',Survey Research Methods, Vol. 1, p. 19-27. 